\title{
Fifty years of digital literacy studies: A meta-research for interdisciplinary and conceptual convergence
}

\author{
María-Cristina Martínez-Bravo; Charo Sádaba-Chalezquer; Javier Serrano-Puche
}

How to cite this article:

Martínez-Bravo, María-Cristina; Sádaba-Chalezquer, Charo; Serrano-Puche, Javier (2020). "Fifty years of digital literacy studies: A meta-research for interdisciplinary and conceptual convergence". Profesional de la información, v. 29, n. 4, e290428.

https://doi.org/10.3145/epi.2020.jul.28

Manuscript received on January $10^{\text {th }} 2020$ Accepted on June $06^{\text {th }} 2020$
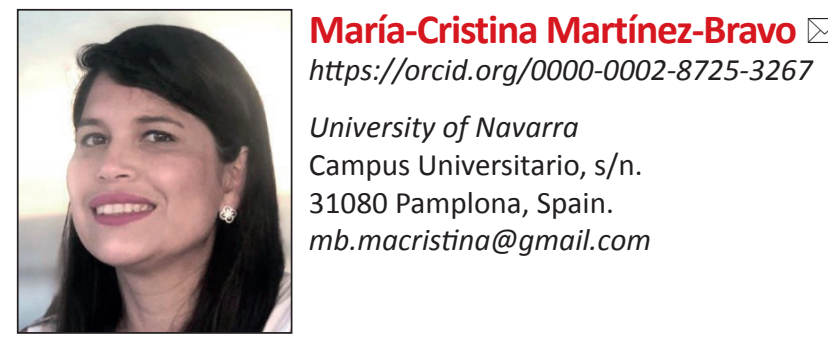

María-Cristina Martínez-Bravo https://orcid.org/0000-0002-8725-3267

University of Navarra

Campus Universitario, $\mathrm{s} / \mathrm{n}$. 31080 Pamplona, Spain. mb.macristina@gmail.com

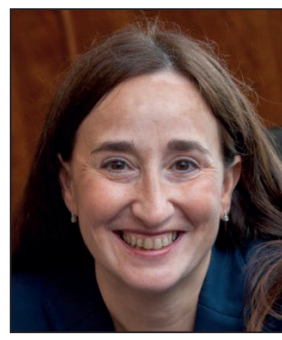

Charo Sádaba-Chalezquer https://orcid.org/0000-0003-2596-2794

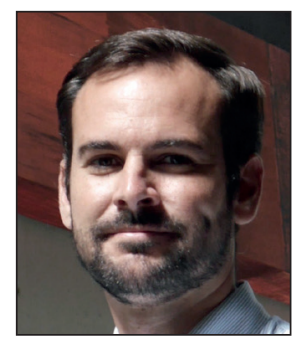
Javier Serrano-Puche
https://orcid.org/0000-0001-6633-5303
University of Navarra
Department of Public Communication
Campus Universitario, $\mathrm{s} / \mathrm{n}$.
31080 Pamplona, Spain.
jserrano@unav.es

\begin{abstract}
The following research has as its starting point the previous existence of different approaches to the study of digital literacy, which reflect a specialisation by area of study as well as connections and complementarity between them. The paper analyses research from the last 50 years through 11 key terms associated with the study of this subject. The article seeks to understand the contribution of each term for an integrated conceptualisation of digital literacy. From the data science approach, the methodology used is based on a systematized review of the literature and a network analysis using Gephi. The study analyses 16,753 articles from WoS and 5,809 from Scopus, between the period of 1968 to 2017. The results present the input to each key term studied as a map of keywords and a conceptual framework in different levels of analysis; in these, we show digital literacy as a central term that connects and integrates the others, and we define it as a process that integrates all the perspectives. The conclusions emphasise the comprehensive sense of digital literacy and its social condition, as well as the transversality to human life. This research aims to understand the relationships that exist between the different areas and contribute to the debate from a meta-theoretical level, validating meta-research for this interdisciplinary purpose.
\end{abstract}

\section{Keywords}

Digital literacy; Media literacy; Information literacy; New literacies; Digital divide; Lifelong learning; $21^{\text {st }}$ century skills; Critical literacy; Learning motivations; Curriculum; Digital culture; Network analysis; Meta-research; Data science.

\section{Introduction}

Digital literacy or digital competence (i.e. information literacy, ICT skills, technological literacy) is part of the competencies for lifelong learning. Voogt and Pareja-Roblin (2012) highlight that, in the different proposals for competence frameworks, emphasis is placed on the 'digital' as the central competence and as the axis for strengthening other competences. 
The concept 'digital literacy' integrates digital skills and $21^{\text {st }}$ century skills. It was introduced in 1998 by Gilster (Van-Laar et al., 2017), and is considered as the ability that allows users to perform intuitively in digital environments to easily and effectively access the wide range of knowledge embedded in those environments. It is also considered more than a technical skill involving the use of software and digital devices, as it also includes a cognitive and socio-emotional dimension to problem solving in the digital environment (Eshet-Alkalai, 2004; Martin, 2006; Ilomäki; Kantosalo; Lakkala, 2011). Digital literacy enables the development of skills for the safe and critical use of ICT, learning, personal growth and participation in society (European Commission, 2007; Ala-Mutka; Punie; Redecker, 2013; Vuorikari et al., 2016).

The concept of digital literacy is not standardised, as the scope is broad and has been researched from different fields. The most common approaches so far have been those of media studies, educational studies, computer science, information science and librarianship (Ilomäki et al., 2016). Due to this, the understanding of this competence can be diverse.

Several terms have been identified by researchers to refer to digital literacy: information literacy, digital competence, digital skills, new literacies, multiliteracies, media literacy, e-literacy, internet literacy, ICT Skills, ICT Competence, ICT Literacy, meta-literacy, computer literacy, computer skills, e-competence, e-skills, and technology literacy (Martin, 2006; Bawden, 2008; Gillen; Barton, 2010; Mackey; Jacobson, 2010; Ilomäki; Kantosalo; Lakkala, 2011; Ferrari, 2012; Aesaert et al., 2013; Gallardo-Echanique et al. 2015; Van-Laar et al., 2017; Siddiq; Gochyyev; Wilson, 2017).

In part, the different denominations of digital literacy respond to the interests and scope of each era. It emerged at the end of the twentieth century with the spread of ICT, so in the early eighties of the last century the term mainly referred to computer literacy, focusing on the handling of software and hardware (Naval et al., 2016).

The critical approach of this competence has been growing in the various research perspectives, especially in concepts such as digital literacy, information literacy and media literacy (Buckingham, 2003; Aguaded; Marín-Gutiérrez; Caldeiro-Pedreira, 2018; Redecker; Punie, 2019). The approach to educational technology and media literacy studies not only highlight this critical dimension, but also provides an emotional perspective which, in addition to the so-called critical thinking, refers to a "critical attitude" (Ferrés; Masanet; Mateus, 2018)

Finally, it is important to highlight that digital literacy

"has been one of those key concepts whose relevancy and weight as a key element for a digital citizenship have shifted from being recommended to essential" (Pérez-Escoda; García-Ruiz; Aguaded, 2019).

As these researchers point out, this competence has become a training requirement for different international bodies such as the European Commission, Unesco, and OECD.

The various concepts have been defined by different authors (Table 1). Some of these have a greater focus on certain competences, and therefore the potential to complement each other, while other terms are more comprehensive.

Table 1. Definition of the key terms studied.

\begin{tabular}{|c|c|c|}
\hline Key term & Publication & Autor \\
\hline Information literacy & Information literacy - A core competency & Burnhein (1992) \\
\hline New literacies & $\begin{array}{l}\text { New literacies: A dual-level theory of the changing nature of } \\
\text { literacy }\end{array}$ & Leu et al. (2017) \\
\hline Digital literacy & What is digital competence? & Ilomäki; Kantosalo; Lakkala (2011) \\
\hline Digital skills & $\begin{array}{l}\text { A new direction?: Digital literacy, student participation and } \\
\text { curriculum reform in Norway }\end{array}$ & Erstad (2006) \\
\hline Media literacy & Alfabetización mediática y nuevo humanismo & Pérez-Tornero; Varis (2012) \\
\hline Technology literacy & $\begin{array}{l}\text { Standards for technological literacy: Contents for the study of } \\
\text { technology }\end{array}$ & $\begin{array}{l}\text { International Technology Education Association (ITEA) } \\
\text { (2007) }\end{array}$ \\
\hline Digital competence & $\begin{array}{l}\text { DigComp: A Framework for developing and understanding } \\
\text { digital competence in Europe }\end{array}$ & Ferrari (2013) \\
\hline ICT skills & Terminology of European education and training policy & $\begin{array}{l}\text { European Centre for the Development of Vocational } \\
\text { Training (Cedefop) (2014) }\end{array}$ \\
\hline ICT competence & $\begin{array}{l}\text { A basic model of integration of ICT by teachers: competence } \\
\text { and use. }\end{array}$ & Suárez-Rodríguez et al. (2018) \\
\hline Multiliteracies & Multiliteracies: Literacy learning and the design of social futures & Cope; Kalantzis (1999) \\
\hline ICT literacy & Digital literacies for learning. London: Facet Publishing. & Madigan; Martin (2006) \\
\hline
\end{tabular}

Source: Based on a literary review of scientific publications.

The commonalities of the definitions of these key terms is the user's appropriation and understanding of the technology. Each study perspective supports an integrated concept, and after analysing the relationships between terms at different scales, the results demonstrate the approach of each concept in terms of the subjects researched, which can be visualised in a large network where these relationships converge. 
The main interest of this study is to identify the conceptual contributions of each key term studied, in order to develop an integrated conceptual framework. Starting from the premise of the existence of diverse approaches to the study of the subject, whereby derivables first reflect a dispersion and specialisation by area of study, and which in spite of this, are connected or complementary, we begin with the research question (RQ1): What is the contribution of each term for an integrated conceptualisation of digital literacy? Three secondary questions are derived from this: (RQ1a) What is the structure of the data visualisation that connects the key terms investigated?, (RQ1b) What is the relationship between the different key terms that address the study of digital literacy?, (RQ1c) What are the most important secondary keywords linked to each key term analysed?

The results of the investigation are presented in four sections. The first, second, and third show the findings around the three secondary research questions mentioned in the previous paragraph. This display of the results allows to observe the methodological process and the systematisation of the information, finally leading the reader to the fourth section where the main question of the study is answered. This allows us to conclude that the term "digital literacy" has an important social focus and that it is an integrating concept.

This meta-research from a data science perspective constitutes the first study using a network analysis methodology to shape a conceptual relationship of digital literacy as a set of competences for lifelong learning.

\section{Materials and methods}

This meta-research pursues an interdisciplinary approach in order to integrate the different areas of study that have investigated digital literacy over the last 50 years.

"Meta-research involves taking a panoramic view of science (...) This emphasis on the larger picture is typical of many meta-research investigations" (loannidis et al., 2015).
This meta-research constitutes the first study using a network analysis methodology to shape a conceptual relationship of digital literacy as a key competence for lifelong learning

The meta-analysis starts from a systematic review of metadata (keywords) from 25,562 academic articles, which in turn generate 73,523 connection data, processed with a network analysis.

The 11 keywords for meta-analysis were selected from the following process:

1) A first and exploratory literature review in high-impact academic articles was conducted, as shown in the introduction

2) Second and mainly, eight terms present in the international competency frameworks were selected (in order to delimit the keywords that arose in the previous literature review):

- Information literacy: Unesco, European Commission, Partnership for $21^{\text {st }}$ Century Learning (P21)

- Digital literacy: European Commission, National Educational Technology Standards (NETS)

- Media literacy: Unesco, European Commission, P21

- Technology literacy: NETS, P21, National Assessment of Educational Progress (NAEP)

- Digital competence: European Commission

- ICT skills: NAEP

- ICT competence: European Commission, Unesco

- ICT literacy: P21

3) Finally, based on the high visibility of terms in the network analysis, three terms were added: multiliteracies, new literacies and digital skills.

The selection of keywords was not intended to be exhaustive and that the analysis could be completed with the inclusion of other terms that are also widely used in this area.

\subsection{Systematized literature review}

For the analysis of different perspectives of research about digital literacy, a systematic approach (Booth; Papaioannou; Sutton, 2012) was chosen to synthesize academic literature. This method helps to collect, identify, select and analyse data in an appropriate and reliable manner (Van-Laar et al., 2017).

For this study, we explore academic scientific databases that contain the terms related to digital literacy, and we then complete the process with a network analysis.

This research has its foundations in Web of Science (WoS) and Scopus metadata extracted from 11 selected terms related to digital literacy, which in the context of this research are called 'key terms'. As for the keywords of each scientific article connected to these 'key terms', we use the concept of 'secondary keywords'.

In the context of this document, the term 'digital literacy' will be used to refer to the group of key terms that, depending on the area of study, have a different denomination (Table 1). 


\subsubsection{Search terms and selection criteria}

In order to carry out the study, the following criteria were considered for the systematic review of the literature, prior to the analysis of networks:

1) Period of analysis: the research contains the metadata from articles from 1968, the year when the first results appeared, to 2017, the year when the data was extracted.

2) Key terms: From the preliminary bibliographic review, 11 key terms focused on the study of digital literacy were selected.

3) Scientific data bases: Metadata was obtained from the academic production of WoS and Scopus.

4) Category: The category of results listed as 'academic journals' were selected because they were considered the most significant contributions in the scientific field, as well as those of greater volume, and therefore, more representative in the academic production.

\subsubsection{Network analysis: Data collection and preparation}

Network analysis has often been used to assess links between entities in a network (Grandjean, 2016). It consists of representing a graph with two elements: a set of nodes and a set of lines (De-Nooy; Mrvar; Batagelj, 2005).

In this case, the nodes are formed from the secondary keywords extracted from the scientific articles containing the key terms studied. The lines of the network connect the various keywords to each other and the greater the number of relationships the larger the node is displayed. The analysis of networks was carried out with the free software Gephi, and the algorithm 'modularity class' was applied. This allowed for the understanding of the structure of relations, since the algorithm groups keywords with similar characteristics, meaning it concentrates other keywords that generate subnets according to their relations.

Network analysis has been applied on two scales. The first for the entire extracted database (key terms + secondary terms); and the second applied to a subset of the network formed solely by the key terms of the study.

In the hypothetical example in Figure 1, each keyword represented by the letter ' $K$ ' is part of a modularity, which is differentiated by colour. This type of visualisation of information allows us to determine the density that is greater or lesser, and the closeness of relationships. In turn, this method allows us to analyse the information both quantitatively (co-occurrence of the number of links between keywords which generates a greater weight to the linked nodes) and qualitatively (role of the keyword and its situation in the network).

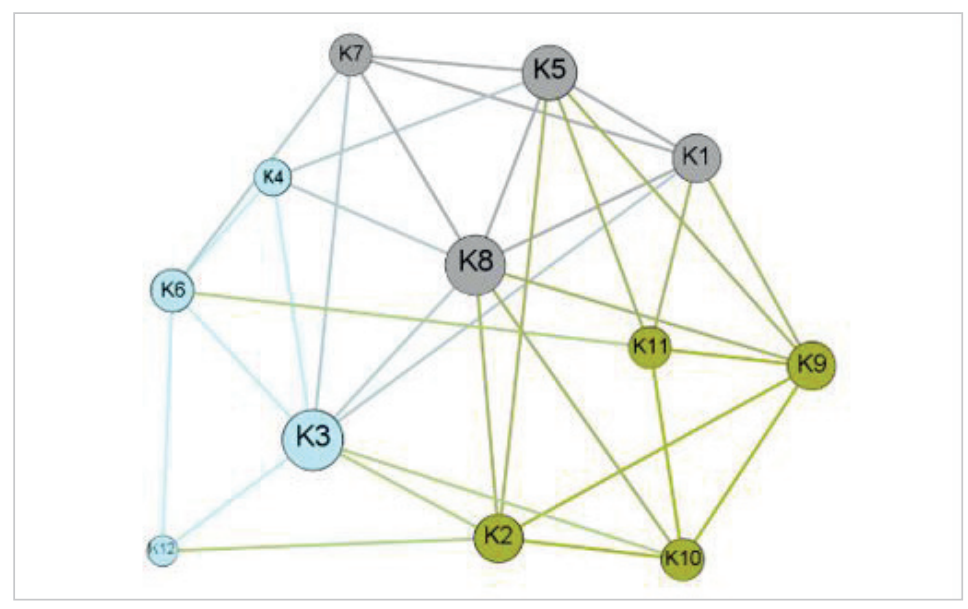

Figure 1. Network analysis methodology implemented. Source: Based on random data in Gephi.

The scientific production over time of each of the terms associated with digital literacy research adds up to 52,903 results in the WoS and Scopus databases. A total of 23,866 WoS and 9,608 Scopus scientific articles were extracted with the selected key terms, of which 16,753 and 5,809 were finally analysed (Table 2), respectively, from a purging of the database.

Table 2. Search results of scientific production with analysed keywords. (Excel)

\begin{tabular}{|c|c|c|c|c|c|c|c|}
\hline Key terms & $\begin{array}{l}\text { WoS Total } \\
\text { results }\end{array}$ & $\begin{array}{c}\text { WoS } \\
\text { academic } \\
\text { articles }\end{array}$ & $\begin{array}{c}\text { WoS } \\
\text { academic } \\
\text { articles } \\
\text { analized }\end{array}$ & $\begin{array}{l}\text { Scopus total } \\
\text { results }\end{array}$ & $\begin{array}{l}\text { Scopus } \\
\text { academic } \\
\text { articles }\end{array}$ & $\begin{array}{c}\text { Scopus } \\
\text { academic } \\
\text { articles } \\
\text { analized }\end{array}$ & $\begin{array}{l}\text { WoS \& Scopus } \\
\text { academic articles } \\
\text { analized }\end{array}$ \\
\hline Information literacy & 9.974 & 7.217 & 6.236 & 6.590 & 4.352 & 2.243 & 8.479 \\
\hline New literacies & 6.063 & 4.401 & 2.905 & 800 & 613 & 362 & 3.267 \\
\hline Digital literacy & 2.698 & 1.672 & 1.541 & 1.636 & 961 & 801 & 2.342 \\
\hline Digital skills & 4.887 & 2.584 & 1.950 & 1.042 & 466 & 246 & 2.196 \\
\hline Media literacy & 3.347 & 2.448 & 1.302 & 1.472 & 1.057 & 808 & 2.110 \\
\hline Technology literacy & 4.758 & 2.938 & 996 & 2.045 & 1.093 & 648 & 1.644 \\
\hline Digital competence & 1.291 & 637 & 603 & 638 & 441 & 148 & 751 \\
\hline ICT skills & 2.425 & 932 & 519 & 374 & 165 & 124 & 643 \\
\hline ICT competence & 1.029 & 413 & 283 & 207 & 128 & 107 & 390 \\
\hline Multiliteracies & 278 & 221 & 210 & 185 & 147 & 163 & 373 \\
\hline ICT literacy & 833 & 403 & 208 & 331 & 185 & 159 & 367 \\
\hline Total & 37.583 & 23.866 & 16.753 & 15.320 & 9.608 & 5.809 & 22.562 \\
\hline
\end{tabular}

Source: Information extracted from Scopus and WoS. 
In order to apply the analysis of networks, data reprocessing was previously carried out, which involved three phases:

- Data cleaning: In this process, key terms and secondary keywords were homogenised (for example, terms such as: ICT with Information and Communication Technologies; e-books with eBooks; $21^{\text {st }}$ century skills with XXI century skills, etc). Categories that are not compatible with the study area were also discarded, and duplicate articles in both databases were eliminated.

- Data structuration: From the database, a co-word analysis was carried out applying a relational unpivot table - which shows the existing relations between each and every one of the keywords, thus generating 73,783 relations between the keywords.

- Data analysis and synthesis: The Gephi tool was used for network analysis and data visualisation as synthesis process for data interpretation.

It should be specified that what gives more significance to a term in the network is not only the number of times it appears, but the number of relationships that this term generates. Therefore, the fact that a term has been researched for a longer time, and as a result, has greater scientific production (greater contribution of keywords to this study), does not mean that it will be the most relevant term, since network analysis considers other algorithms to define that level of importance in the network.

The data obtained contains almost $100 \%$ of the scientific articles within the selected areas produced from 1968 to 2017. It can be considered that approximately $10 \%$ of the articles in the scientific databases did not contain secondary keywords or presented data export errors.

\section{Findings}

\subsection{Mapping the structure of research about digital literacy}

The analysis shows us two structures of relationships; the first, solid, and the second, dispersed. On the one hand, there is the conformation of three main consolidated groups that link to each other (Figure 2), highlighted with yellow circles; and, on the other hand, a dispersed structure of nodes characterised by a lesser integration, indicated with a black circle.

In Figure 2, in which the key terms studied are displayed, we can observe a structure formed by 16 modules (several imperceptible), in which 8 of these have more than 150 nodes, and therefore, have greater relevance within the network. This Figure also highlights 3 key terms in red that have greater visibility and importance within the network.

From this first level of analysis, the term that stands out the most is "information literacy", together with the secondary keywords "assessment" and "academic libraries" which are areas less related to this research. This reflects the fact that this key term covers broader topics and that it is not only linked to the area of digital literacy, but mainly to professionals in librarianship and information sciences.

The second most visible key term on the network is "digital literacy", surrounded by the secondary keywords "literacy", "education", "internet", "ict", and "technology"; terms more focused on the area of this study. In addition, it is centrally related to the term "digital divide", which is a very important node within the entire network, as we will see later.

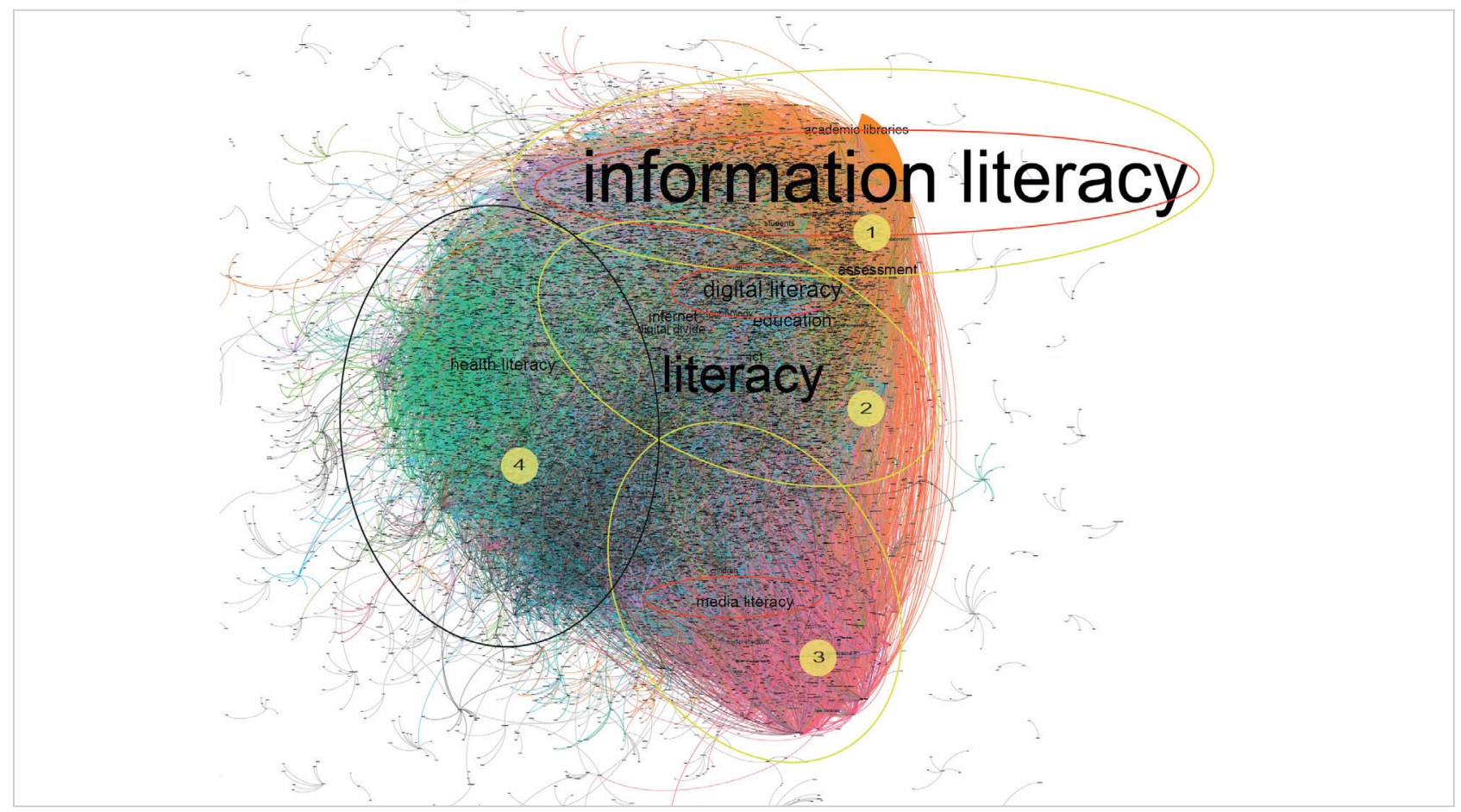

Figure 2. Mapping digital literacy research: key terms structure. Source: Based on data extracted from WoS and Scopus, analysed in Gephi. 
On the other hand, media studies also have an important role within the network, which is reflected in the key term that stands out in the third level as "media literacy". This term explores a wide field that goes beyond digital education and encompasses the critical consumption of media in general (On and Off), and is further manifested in the relation with other terms such as "media", "comprehension" and "new literacies." It also highlights the keywords from the groups "adolescents" and "children", in which these studies are oriented. In this context, it is important to highlight the relationship of new literacies focused on the youngest.

In the scattered area (black circle, area 4), the studies from the health area stand out with the secondary keyword "health literacy," which is related to "communication," and to the central area where the term "digital literacy" is found, therefore referring to a social approach to health linked to ICT. This keyword is not part of the selected terms; however, it has an important visibility and a great relation with the central theme, which is an interesting finding. In this dispersed area, secondary keywords such as "literacy", "technology", "skills", "knowledge", "adolescence”, "scientific literacy", "information" "attitudes" can also be observed, which are transversal terms to the study of the topic and form a connecting area between different modularities (groups of terms).

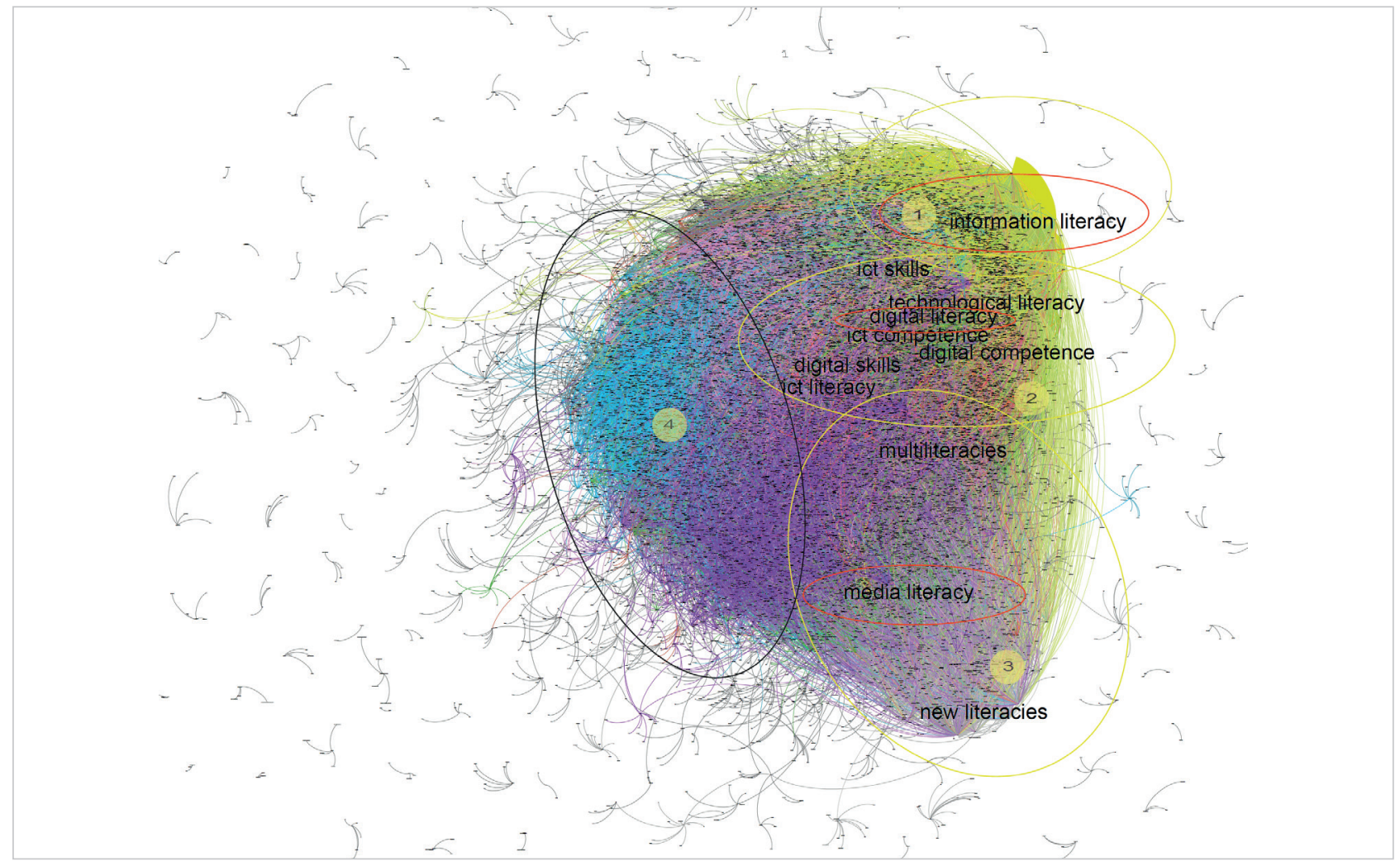

Figure 3. Mapping digital literacy research: Localisation of the key terms studied.

Source: Based on data extracted from WoS and Scopus, analysed in Gephi.

While Figure 2 shows the network with the size of the nodes according to the importance they have in the network; Figure 3 shows the location of all the key terms within the conformed network.

This display allows us to see the structure of stronger and weaker relationships between key terms. This can be attributed to the "modularity class" tool used in network analysis, which determines the set of nodes that are most related to each other and gathers, in this case, the most related terms. The remarkable discovery in this analysis was finding cases where the key terms shared the same modularity (set of similar characteristics), showing a closer relationship. We can also see the opposite case, showing key terms less related to each other.

Table 3 shows the 8 largest modularities, which make up 70\% of the entire network (out of a total of 16 modularities), and whereby the 20 most connected terms in each modularity are identified. The key terms highlighted in green and their location in each modularity have been highlighted in the table.

The modularity "B" has the most key terms clustered (4 of 11): "digital literacy", "digital skills", "technological literacy" and "ict skills" form a single group. Secondly, with 3 key terms clustered, we find the modularity " $A$ ": "digital competence", "ict competence" and "ict literacy"; while the Modularity "C" contains 2 key terms in its group; "new literacies" and "multiliteracies." Therefore, 9 of the 11 key terms are concentrated in 3 modularities.

Moreover, the "D" and "E" modularities contain a studied key term, "information literacy" and "media literacy" respectively, and they do not share modularity with any other studied term. This allows us to understand that although these terms deal with the main focus of this research, they cover many other topics and are more specialised in their area. 
Table 3. Modularities and clustered key terms.

\begin{tabular}{|c|c|c|c|c|c|c|c|}
\hline \multicolumn{8}{|c|}{ Key terms grouped by modularity } \\
\hline $\begin{array}{c}\text { Modularity } \\
\text { A }\end{array}$ & $\begin{array}{c}\text { Modularity } \\
\text { B }\end{array}$ & $\begin{array}{c}\text { Modularity } \\
\text { C }\end{array}$ & $\begin{array}{c}\text { Modularity } \\
\text { D }\end{array}$ & \begin{tabular}{|c} 
Modularity \\
E
\end{tabular} & $\begin{array}{c}\text { Modularity } \\
\text { F }\end{array}$ & $\begin{array}{c}\text { Modularity } \\
\text { G }\end{array}$ & $\begin{array}{c}\text { Modularity } \\
\text { H }\end{array}$ \\
\hline $\begin{array}{l}\text { 1) digital compe- } \\
\text { tence } \\
\text { 2) teacher education } \\
\text { 3) design } \\
\text { 4) teachers } \\
\text { 5) computer-media- } \\
\text { ted communication } \\
\text { 6) ict competence } \\
\text { 7) performance } \\
\text { 8) model } \\
\text { 9) elementary } \\
\text { education } \\
\text { 10) media in edu- } \\
\text { cation } \\
\text { 11) creativity } \\
\text { 12) ict literacy } \\
\text { 13) perceptions } \\
\text { 14) applications in } \\
\text { subject areas } \\
\text { 15) digital game-ba- } \\
\text { sed learning } \\
\text { 16) gender diffe- } \\
\text { rences } \\
\text { 17) secondary } \\
\text { education } \\
\text { 18) computer use } \\
\text { 19)teaching/lear- } \\
\text { ning strategies } \\
\text { 20) teacher training }\end{array}$ & $\begin{array}{l}\text { 1) digital literacy } \\
\text { 2) digital divide } \\
\text { 3) internet } \\
\text { 4) ict } \\
\text { 5) social media } \\
\text { 6) computer } \\
\text { literacy } \\
\text { 7) gender } \\
\text { 8) collaborative } \\
\text { learning } \\
\text { 9) competences } \\
\text { 10) web } 2.0 \\
\text { 11) digital skills } \\
\text { 12) computers } \\
\text { 13) web } \\
\text { 14) online } \\
\text { 15) identity } \\
\text { 16) community } \\
\text { 17) access } \\
\text { 18) information } \\
\text { and communica- } \\
\text { tion technology } \\
\text { 19) internet use } \\
\text { 20) digital } \\
\text { inequality } \\
\text { (35) technologi- } \\
\text { cal literacy } \\
\text { (77) ict skills }\end{array}$ & $\begin{array}{l}\text { 1) adolescence } \\
\text { 2) digital } \\
\text { 3) comprehension } \\
\text { 4) new literacies } \\
\text { 5) multiliteracies } \\
\text { 6) writing } \\
\text { 7) early adoles- } \\
\text { cence } \\
\text { 8) critical literacy } \\
\text { 9) childhood } \\
\text { 10) motivation } \\
\text { 11) case study } \\
\text { 12) university } \\
\text { students } \\
\text { 13) visual literacy } \\
\text { 14) strategies } \\
\text { 15) information } \\
\text { and communica- } \\
\text { tion technologies } \\
\text { 16) content } \\
\text { literacy } \\
\text { 17) action } \\
\text { research } \\
\text { 18) digital/media } \\
\text { literacies } \\
\text { 19) policy } \\
\text { 20) engagement }\end{array}$ & $\begin{array}{l}\text { 1) information } \\
\text { literacy } \\
\text { 2) academic } \\
\text { libraries } \\
\text { 3) assessment } \\
\text { 4) students } \\
\text { 5) higher edu- } \\
\text { cation } \\
\text { 6) collaboration } \\
\text { 7) critical thinking } \\
\text { 8) library instruc- } \\
\text { tion } \\
\text { 9) e-learning } \\
\text { 10) learning } \\
\text { 11) digital libraries } \\
\text { 12) academic } \\
\text { literacy } \\
\text { 13) libraries } \\
\text { 14) active learning } \\
\text { 15) evaluation } \\
\text { 16) } 21 \text { st century } \\
\text { skills } \\
\text { 17) distance } \\
\text { education } \\
\text { 18) digital natives } \\
\text { 19) information } \\
\text { retrieval } \\
\text { 20) blended } \\
\text { learning }\end{array}$ & $\begin{array}{l}\text { 1) media } \\
\text { literacy } \\
\text { 2) education } \\
\text { 3) media } \\
\text { 4) adolescents } \\
\text { 5) media edu- } \\
\text { cation } \\
\text { 6) curriculum } \\
\text { 7) pedagogy } \\
\text { 8) citizenship } \\
\text { 9) youth } \\
\text { 10) compe- } \\
\text { tence } \\
\text { 11) videoga- } \\
\text { mes } \\
\text { 12) media } \\
\text { competence } \\
\text { 13) critical } \\
\text { media literacy } \\
\text { 14) television } \\
\text { 15) advertising } \\
\text { 16) schools } \\
\text { 17) civic enga- } \\
\text { gement } \\
\text { 18) agency } \\
\text { 19) mass media } \\
\text { 20) audiences }\end{array}$ & $\begin{array}{l}\text { 1) literacy } \\
\text { 2) technology } \\
\text { 3) children } \\
\text { 4) skills } \\
\text { 5) reading } \\
\text { 6) instruction } \\
\text { 7) multimo- } \\
\text { dality } \\
\text { 8) language } \\
\text { 9) digital media } \\
\text { 10) classroom } \\
\text { 11) school } \\
\text { 12) professio- } \\
\text { nal develop- } \\
\text { ment } \\
\text { 13) early } \\
\text { literacy } \\
\text { 14) phonologi- } \\
\text { cal awareness } \\
\text { 15) digital } \\
\text { storytelling } \\
\text { 16) emergent } \\
\text { literacy } \\
\text { 17) achieve- } \\
\text { ment } \\
\text { 18) vocabulary } \\
\text { 19) dyslexia } \\
\text { 20) culture }\end{array}$ & $\begin{array}{l}\text { 1) health literacy } \\
\text { 2) information } \\
\text { 3) communica- } \\
\text { tion } \\
\text { 4) informa- } \\
\text { tion-seeking } \\
\text { 5) consumer } \\
\text { health informa- } \\
\text { tion } \\
\text { 6) self-efficacy } \\
\text { 7) behavior } \\
\text { 8) impact } \\
\text { 9) numeracy } \\
\text { 10) readability } \\
\text { 11) information } \\
\text { seeking beha- } \\
\text { viour } \\
\text { 12) care } \\
\text { 13) cancer } \\
\text { 14) patient } \\
\text { education } \\
\text { 15) adults } \\
\text { 16) health com- } \\
\text { munication } \\
\text { 17) health } \\
\text { 18) health infor- } \\
\text { mation } \\
\text { 19) outcomes } \\
\text { 20) financial } \\
\text { literacy }\end{array}$ & $\begin{array}{l}\text { 1) knowledge } \\
\text { 2) attitudes } \\
\text { 3) scientific } \\
\text { literacy } \\
\text { 4) science } \\
\text { 5) science } \\
\text { education } \\
\text { 6) credibility } \\
\text { 7) beliefs } \\
\text { 8) socioscienti- } \\
\text { fic issues } \\
\text { 9) discourse } \\
\text { 10) framework } \\
\text { 11) science } \\
\text { communication } \\
\text { 12) argumen- } \\
\text { tation } \\
\text { 13) inquiry } \\
\text { 14) trust } \\
\text { 15) science } \\
\text { literacy } \\
\text { 16) media and } \\
\text { science } \\
\text { 17) biology } \\
\text { 18) chemistry } \\
\text { 19) reasoning } \\
\text { 20) Wikipedia }\end{array}$ \\
\hline
\end{tabular}

Source: Based on data extracted from WoS and Scopus, analysed in Gephi.

The modularity with the most association of key terms researched (modularity B) is the one that corresponds to the key terms "digital literacy," "digital skills," "ICT literacy" and "technological literacy." It is the fourth modularity in size, with 12,963 keywords associated in this group.

Also, the 3 remaining modularities ( $F, G$ and $H$ ) are modularities that are located in the dispersed area of the network structure, appearing as a connecting area with themes and literacies that enrich the results. For example, health literacy, science literacy, financial literacy, etc.

This first level of analysis provides the structure of the visualisation of data, as well as relations and nodes with greater significance, where the key term digital literacy is shown as a more integrating term and focused.

\section{2. 'Digital literacy' an integrated and connected concept}

In the first section of the results, we analyse the relationship of the key terms in the large set as well as the relationship structure with other secondary keywords. Furthermore, the key terms are analysed in relation to themselves and their relevance within the network as a whole.

Therefore, this section focuses on the subnet formed by the key terms; this level change in the analysis shows the number of relationships between these terms. A co-occurrence matrix is used in which the set of key terms is listed horizontally and vertically (Table 4). The last two rows of the table present the total relations corresponding to each term and the percentage.

The inter-relations between the terms analysed are concentrated. Two key terms, "digital literacy" and "media literacy," generate more than half of these relations (52\%), and if the next three terms "information literacy", "digital competence" and "new literacies" are considered in terms of importance, $85 \%$ of generated relations are achieved.

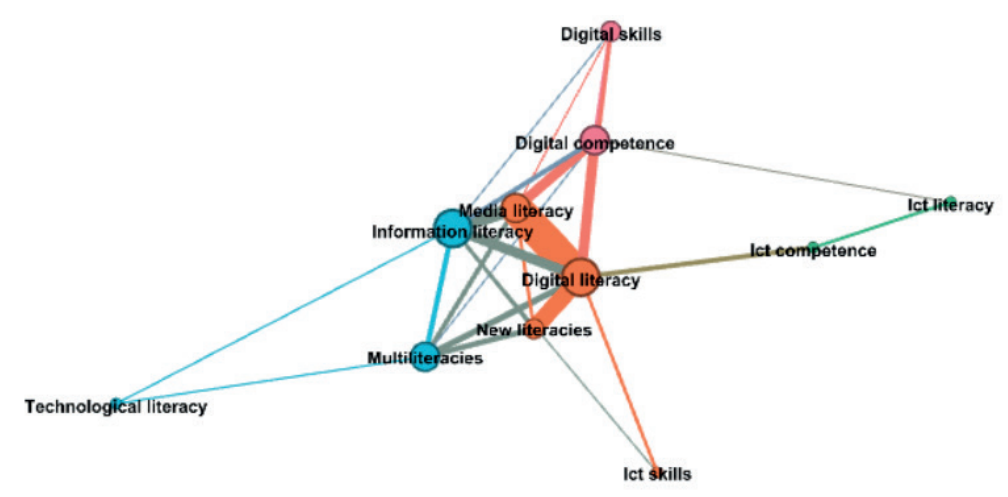

Figure 4. Subnetwork of key terms.

Source: Based on data extracted in WoS and Scopus, analysed in Gephi. 
Table 4. Co-occurrence matrix of key terms studied.

\begin{tabular}{|c|c|c|c|c|c|c|c|c|c|c|c|}
\hline Key terms & $\begin{array}{c}\text { Tech- } \\
\text { nology } \\
\text { literacy }\end{array}$ & $\begin{array}{c}\text { ICT } \\
\text { literacy }\end{array}$ & $\begin{array}{l}\text { ICT } \\
\text { skills }\end{array}$ & $\begin{array}{l}\text { ICT com- } \\
\text { petence }\end{array}$ & $\begin{array}{l}\text { Digital } \\
\text { skills }\end{array}$ & $\begin{array}{l}\text { Multi-li- } \\
\text { teracies }\end{array}$ & $\begin{array}{l}\text { New lite- } \\
\text { racies }\end{array}$ & $\begin{array}{c}\text { Digital } \\
\text { compe- } \\
\text { tence }\end{array}$ & $\begin{array}{l}\text { Infor- } \\
\text { mation } \\
\text { literacy }\end{array}$ & $\begin{array}{c}\text { Media } \\
\text { literacy }\end{array}$ & $\begin{array}{l}\text { Digital } \\
\text { literacy }\end{array}$ \\
\hline $\begin{array}{l}\text { Technology } \\
\text { literacy }\end{array}$ & $x$ & 0 & 0 & 0 & 0 & 1 & 0 & 0 & 1 & 0 & 0 \\
\hline ICT literacy & 0 & $x$ & 0 & 3 & 0 & 0 & 0 & 1 & 0 & 0 & 0 \\
\hline ICT skills & 0 & 0 & $x$ & 0 & 0 & 0 & 0 & 0 & 1 & 0 & 3 \\
\hline $\begin{array}{l}\text { ICT } \\
\text { competence }\end{array}$ & 0 & 3 & 0 & $x$ & 0 & 0 & 0 & 0 & 0 & 0 & 5 \\
\hline Digital skills & 0 & 0 & 0 & 0 & $x$ & 0 & 0 & 5 & 1 & 1 & 4 \\
\hline Multiliteracies & 1 & 0 & 0 & 0 & 0 & $x$ & 6 & 1 & 5 & 5 & 7 \\
\hline New literacies & 0 & 0 & 0 & 0 & 0 & 6 & $x$ & 0 & 4 & 3 & 21 \\
\hline $\begin{array}{l}\text { Digital com- } \\
\text { petence }\end{array}$ & 0 & 1 & 0 & 0 & 5 & 1 & 0 & $x$ & 5 & 12 & 12 \\
\hline $\begin{array}{l}\text { Information } \\
\text { literacy }\end{array}$ & 1 & 0 & 1 & 0 & 1 & 5 & 4 & 5 & $x$ & 16 & 12 \\
\hline Media literacy & 0 & 0 & 0 & 0 & 1 & 5 & 3 & 12 & 16 & $x$ & 40 \\
\hline $\begin{array}{l}\text { Digital lite- } \\
\text { racy }\end{array}$ & 0 & 0 & 3 & 5 & 4 & 7 & 21 & 12 & 12 & 40 & $x$ \\
\hline $\begin{array}{l}\text { Total rela- } \\
\text { tionships }\end{array}$ & 2 & 4 & 4 & 8 & 11 & 25 & 34 & 36 & 45 & 77 & 104 \\
\hline $\begin{array}{l}\% \text { of rela- } \\
\text { tionships }\end{array}$ & $1 \%$ & $1 \%$ & $1 \%$ & $2 \%$ & $3 \%$ & $7 \%$ & $10 \%$ & $10 \%$ & $13 \%$ & $22 \%$ & $30 \%$ \\
\hline
\end{tabular}

Source: Based on data extracted from WoS and Scopus, analysed in Gephi.

"Digital literacy" is the term that generates the greatest connectivity (Figure 4), as it establishes relations with eight of the ten key terms, which is reflected in the highest value (11.9) of 'betweennes centrality.' In this sub-network, this indicator shows the degree of interconnection that the node allows within the network. In other words, "digital literacy" is characterised by a high number of relationships, as well as by its role as a central link between the different key terms of the subnet.

On the other hand, the five least related terms (digital skills, ict competence, ict skills, ict literacy and technological literacy) do not reach even $10 \%$ of the relationships between them.

\subsection{The social condition of digital literacy}

The first two result sections cover first, the structure of the network as a whole, and the interrelation of the key terms studied in that aggregate. In this section we analyse the secondary keywords or descriptors associated to each one of the 11 key terms, this will allow us to see their thematic contribution to the overall relation.

Table 5 presents the key terms and their relevance in the network in relation to themselves and the secondary keywords. The degree is the number of nodes (contained keywords) and the weighted degree is the number of relations (connections that form the nodes or keywords). Each relationship characterises the study approach of each key term.

In table 6, we observe the ranking of the 50 most connected words in the whole network. The table shows the most important keywords, and where the key terms are. Their position within this ranking is highlighted in green. This set of data represents an extended definition, which will be considered in the final section of the results, in a comprehensive approach that aims to collect the different perspectives.
Table 5. Key terms. Ranking of relations.

\begin{tabular}{|l|c|c|c|}
\hline \multicolumn{1}{|c|}{ Keyword } & $\begin{array}{c}\text { Modularity } \\
\text { class }\end{array}$ & Degree & $\begin{array}{c}\text { Weighted } \\
\text { degree }\end{array}$ \\
\hline information literacy & D & 1,537 & 3,538 \\
\hline digital literacy & B & 804 & 1,790 \\
\hline media literacy & C & 643 & 1,302 \\
\hline new literacies & E & 257 & 573 \\
\hline digital competence & A & 262 & 506 \\
\hline multiliteracies & E & 245 & 350 \\
\hline ict competence & A & 127 & 197 \\
\hline digital skills & B & 122 & 192 \\
\hline ict literacy & A & 89 & 131 \\
\hline technological literacy & B & 66 & 87 \\
\hline ict skills & B & 29 & 42 \\
\hline
\end{tabular}

Source: Based on data extracted from WoS and Scopus, analysed in Gephi. 
Table 7, meanwhile, contains the first 20 words most related to each of the key terms. Here we highlight the term "digital literacy" in yellow, which is shown to be more connected with the other ter$\mathrm{ms}$ with greater repetition and relevance (position), as it is in the first positions of the blocks of keywords and modularities. The other key terms and their repetitions are highlighted in blue. Also highlighted in green we find the secondary keyword with the greatest repetition ("digital divi$\mathrm{de}^{\prime}$ ) associated with the key terms.

From this third level of analysis, the most important research topics associated with each key term stand out. The block of terms of modularity " $A$ " is more focused on the pedagogical area of digital literacy, related to teachers and ICT; and block " $B$ ", to the different competences (especially basic: technique, communication, information, media, collaboration), as well as the learning environments and results of the students.

Block " $\mathrm{C}$ ", from a critical literacy approach, is oriented to the connection with different realities, intercultural communication, gender, culture, finance; that is to say, diverse contexts of life connected with technology.

Furthermore, the blocks with modularity $D$ and $E$ also include competencies, which although are basic or linear (information, communication and media), their approach is more transversal with the development of critical thinking and the construction of digital citizenship.

Finally, the results of this section highlight two terms: "digital literacy" and "digital divide". The first integrates all the concepts; the second deepens the social condition of technology, an approach sometimes lost by the technical perspective. This network of keywords allows us to outline the integrated framework, which will be described in the following section.

\subsection{Convergence: towards an integrated conceptual framework}

In the previous sections, all key terms are framed in the inclusive term "digital literacy". First, because it is the most targeted term, and secondly, because it is the most central and connected of the other 10 terms studied.

This section proposes an integrated conceptual framework that considers different elements: actors, strategies, competencies, and ecosystems, which are outlined in a table that integrates the different levels of analysis of the results.

Table 8 therefore, is the extract of the approach of each key term, in which there are four levels of results: 1) The 5 keywords most related to the modularity, 2) The 5 secondary keywords most related to each key term, 3) The description of the approach of each key term and 4) The description of the approach from the modularity.

It is important to mention that secondary keywords have been highlighted in the analysis. These give value to the different perspectives of studies and have been integrated conceptually by their importance and weight in the network. Both the key terms and the secondary keywords of greater frequency have been indicated and differentiated by colour in Table 8 .

This integrated perspective sees digital literacy as more than the sum of competencies. Rather, it looks at it as a process for subtracting the digital divide, starting with the analysis and exploration of literacies, curricular planning and design, and then reaching the user-subject who is endowed with these diverse competencies specialising in multiple areas and approaches such as; social, technical, critical. From this process perspective, there are different actors and stages. 


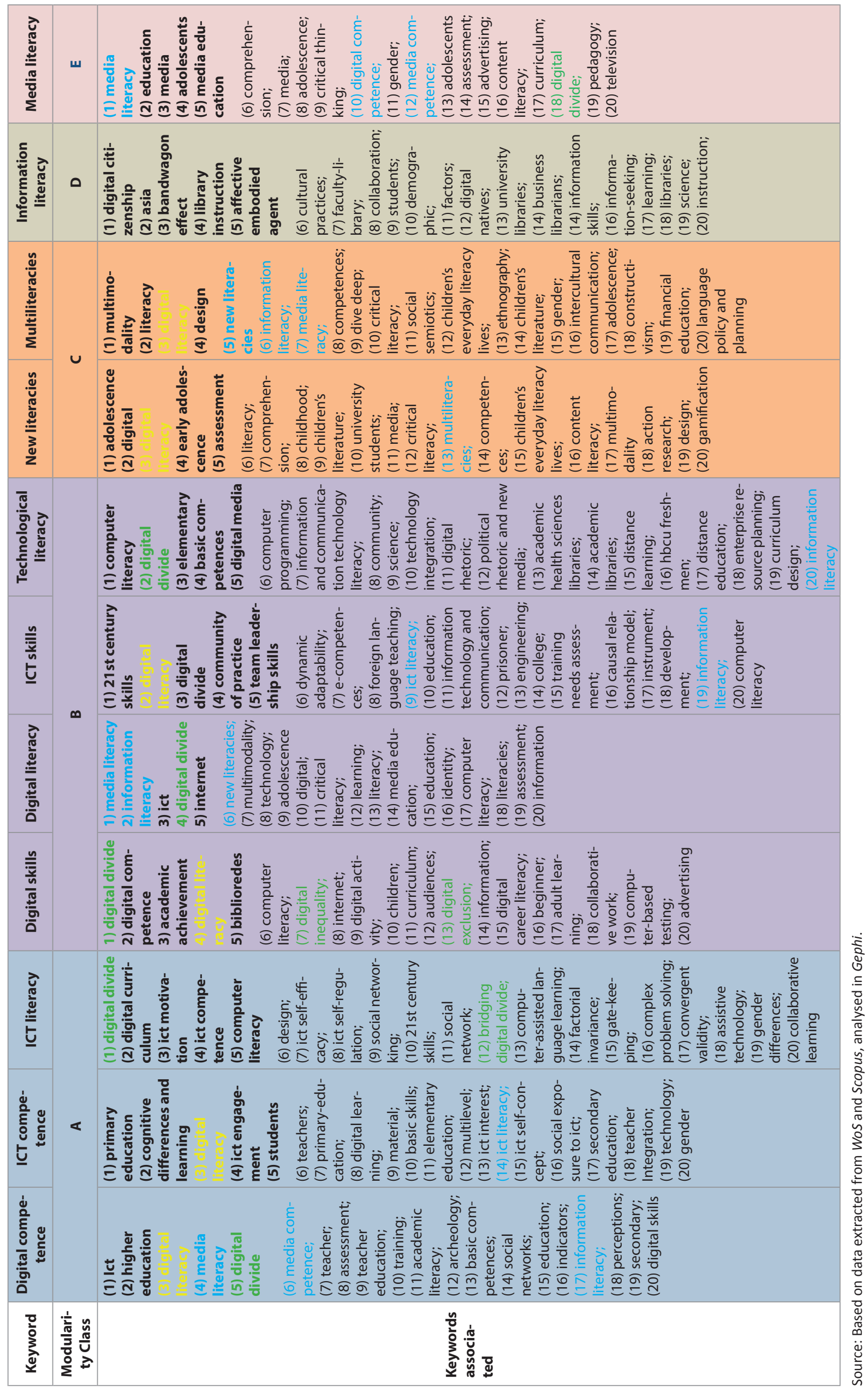




\begin{tabular}{|c|c|c|c|c|}
\hline 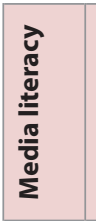 & 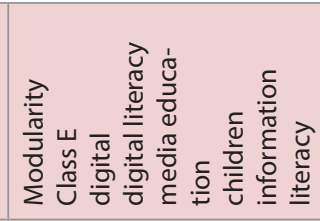 & 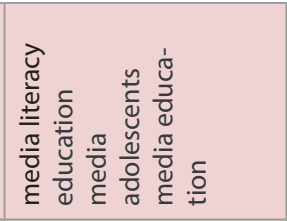 & 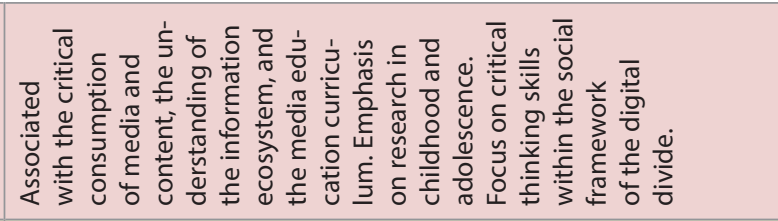 & 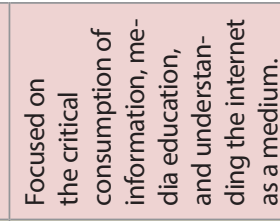 \\
\hline 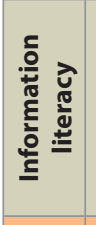 & 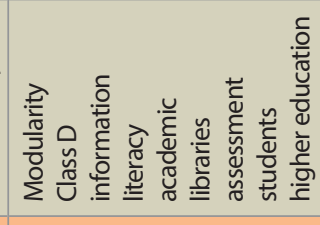 & 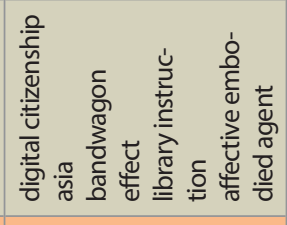 & 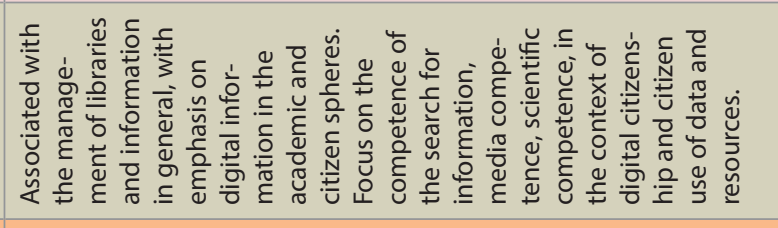 & 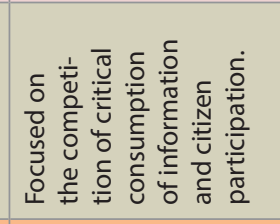 \\
\hline 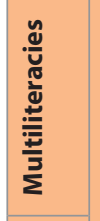 & \multirow[b]{2}{*}{ 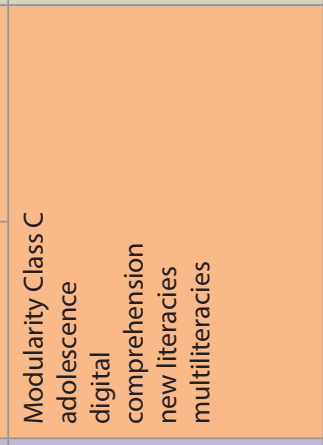 } & 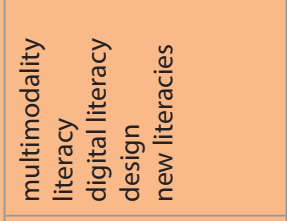 & 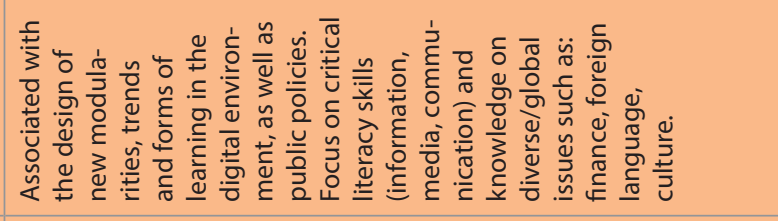 & \multirow{2}{*}{ 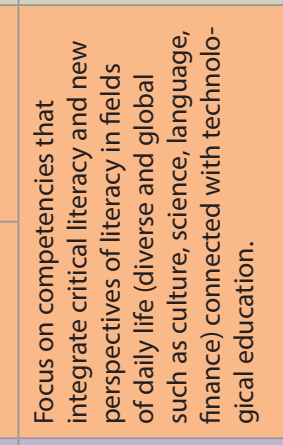 } \\
\hline 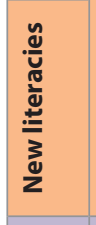 & & 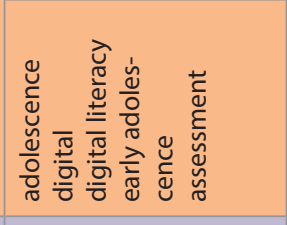 & 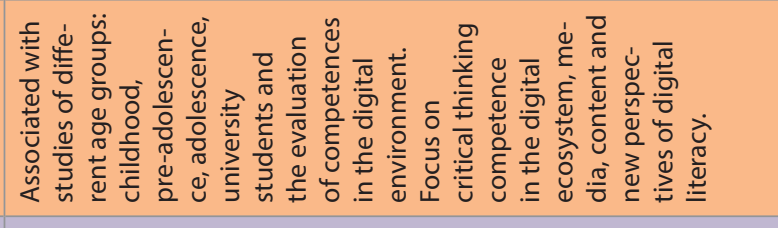 & \\
\hline \multirow[t]{2}{*}{ 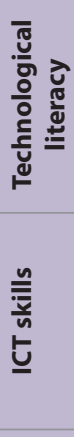 } & \multirow[b]{4}{*}{ 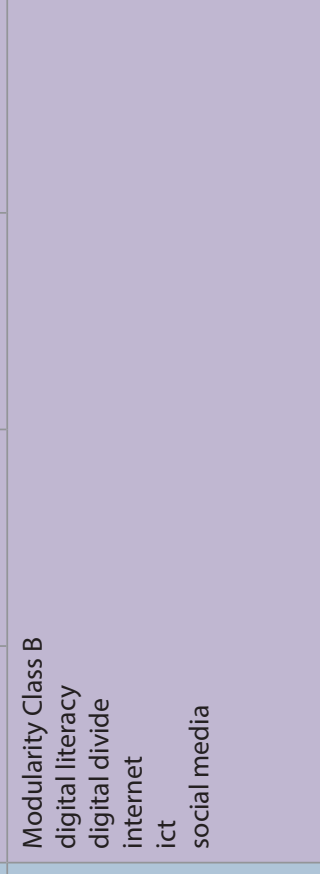 } & 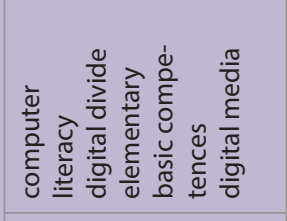 & 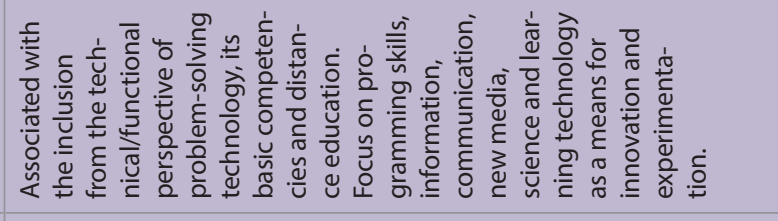 & \multirow{4}{*}{ 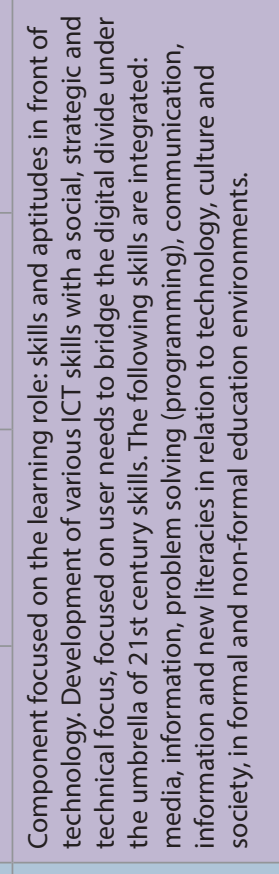 } \\
\hline & & 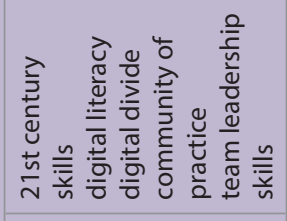 & 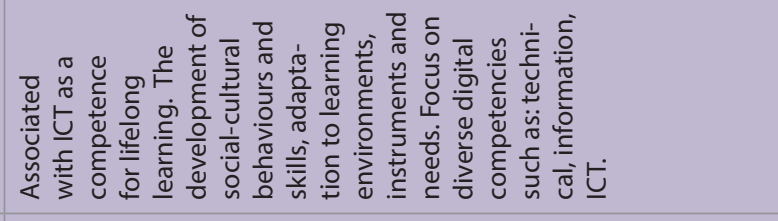 & \\
\hline 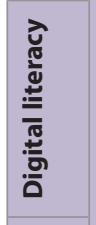 & & \multirow{2}{*}{ 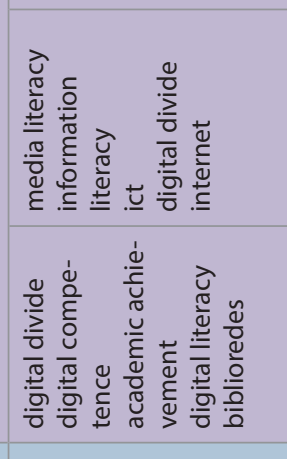 } & 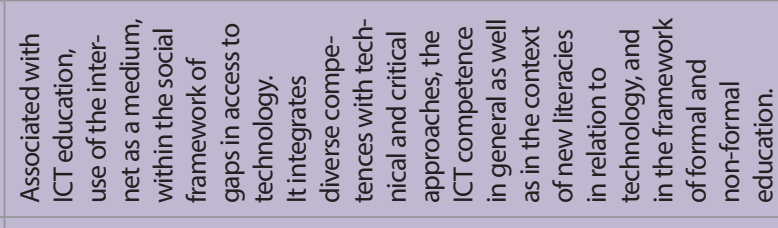 & \\
\hline 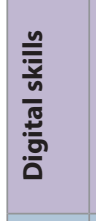 & & & 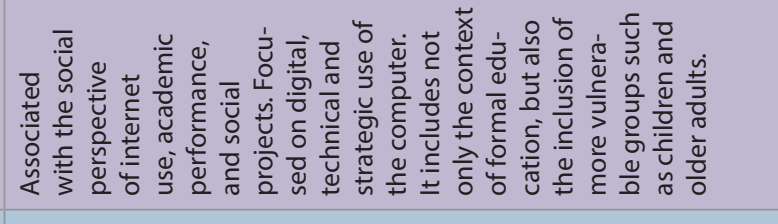 & \\
\hline 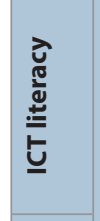 & \multirow{3}{*}{ 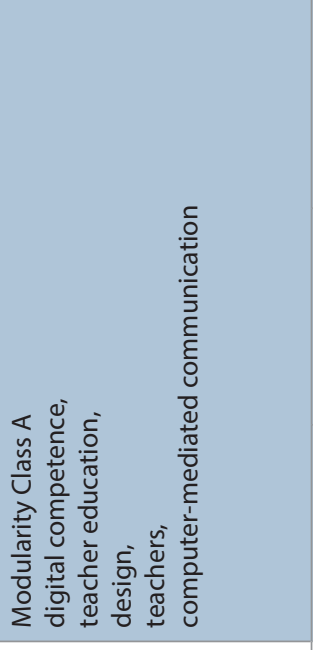 } & 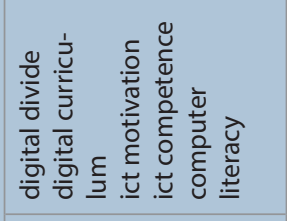 & 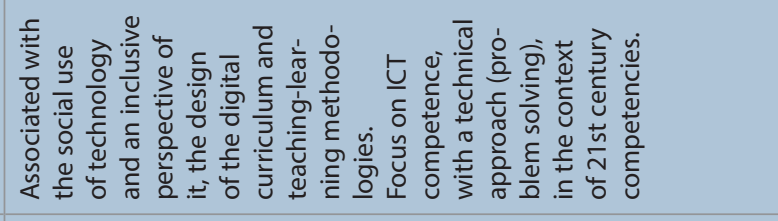 & \multirow{3}{*}{ 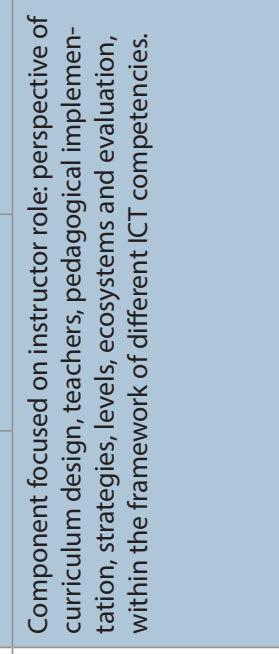 } \\
\hline 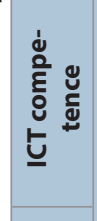 & & 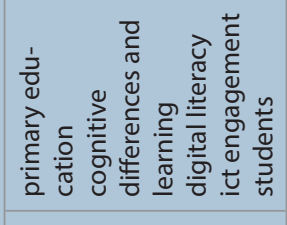 & 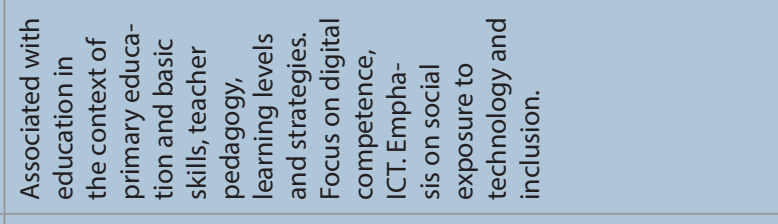 & \\
\hline 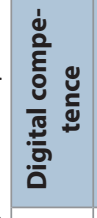 & & 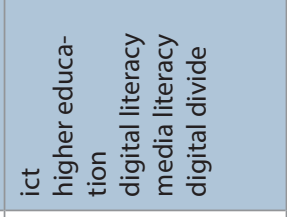 & 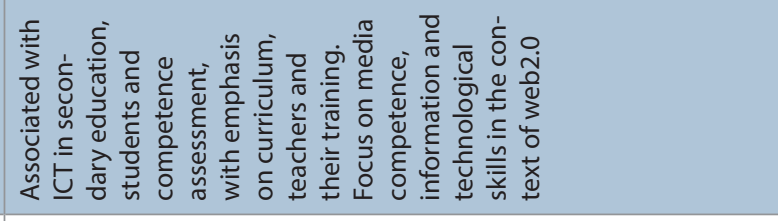 & \\
\hline & 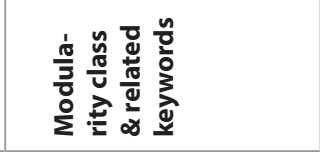 & 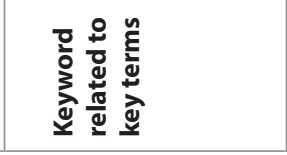 & 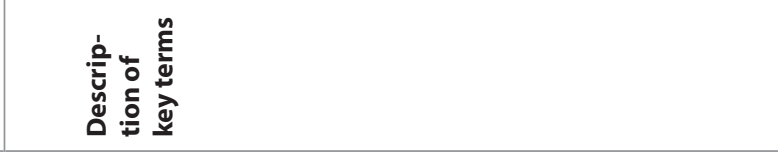 & 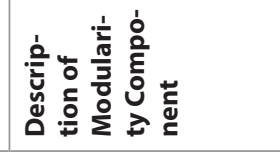 \\
\hline
\end{tabular}


Moreover, this vision does not only focus on the "what?" of competence, that is, "what am I going to teach?" (curriculum), but also on the "how?" (strategies, pedagogies, ecosystems) and the "why?" or "what for?" associated with learning objectives and needs, and specifically, with the reduction of the digital divide.

This systematisation of information leads us to propose a more comprehensive definition:

Digital literacy encompasses two perspectives: the first, focusing on skills-competencies for the use of technology at the personal, professional and citizen level; the second, on teaching-learning and its strategies, both in the context of lifelong learning and 21st century competencies. It also integrates two actors in different roles: 1) instructor/executor and 2) user-learner.

From the first perspective, digital literacy implies the development of competencies for the effective, critical, strategic, social, technical, creative and healthy management of technology (ICT) in different environments (formal-informal); the participation in the digital ecosystem and the appropriation of different innovations. On the other hand, the second perspective focuses on curriculum design, planning, implementation, and evaluation of competencies. Both visions aim at digital inclusion and to break down the digital divide.
Digital literacy encompasses two perspectives: the first, focusing on skills-competencies for the use of technology at the personal, professional and citizen level; the second, on teaching-learning and its strategies for digital literacy

This proposal of definition, integrating the different approaches, is the result of a dialogue between different areas of knowledge, of an analysis of meeting points, and the association of the contributions of each specialty. From this point of view, digital literacy is a process with different actors, within the social framework of digital inclusion

\section{Discussion}

As it is observed throughout this research, digital literacy encompasses a diversity of subjects, which in turn explains the different perspectives that enrich the study. Viewing the subject from an integral perspective can refocus research, as well as limit it in its components.

Beyond an unifying term, it is key to orient the comprehensive perspective to the contribution that each term can make to the concept of digital literacy and how each one contributes, within its field of specialisation, with a sum of essentials that develop a macro concept that connects with the competencies of the $21^{\text {st }}$ century skills.

It is important to emphasize that the breadth of the subject, in turn, requires an interdisciplinary vision, which could be methodologically enriched with a Delphi method for the interpretation and discussion of results.

In terms of research on the subject, within the framework of lifelong learning, digital literacy has been framed in studies in specific populations such as childhood and adolescence, giving less focus to other target groups. Therefore, it is vital to visualise digital literacy, not only within the framework of formal education, but also to strengthen research on the subject in informal education (Scolari et al.), citizenship and vulnerable groups.

The most crucial finding to the study of digital literacy is to situate the subject within the social framework of 'digital divide', an approach that seeks social inclusion, equity and access to knowledge, which is extremely important in the information and knowledge society (Van-Deursen; Van-Dijk, 2014; Martínez-Bravo; Sádaba-Chalezquer; Serrano-Puche, 2018), and can sometimes be lost in a solely technical and instrumental view of technology, surpassed in the concept of 'digital literacy' (Ilomäki; Kantosalo; Lakkala, 2011). Disconnecting the user's learning needs and motivations can result in making the digital divide more complex.

Other study perspectives have also turned out to be interesting findings, such as the one in the field of health with the approach of "health literacy" (Van-Deursen, 2012) or the vision of digital literacy from the professional and scientific approaches (Leahy; Wilson, 2014). Seeing digital literacy from a cross-cutting approach to human life is a pending challenge.

As for the methodology applied, it is limited to the precision with which authors identify their articles with keywords. In addition, secondary keywords associated with scientific production do not always determine the entire content of the contribution. Also, when working with such a dense database, some factors could go unnoticed.

It is also important to point out that throughout the research process and data processing we identified other terms of interest that have been left out of the analysis such as: computer literacy, e-literacy, internet literacy, among others, which should be considered in future studies.
The most crucial finding to the study of digital literacy is to situate the subject within the social framework of 'digital divide', an approach that seeks social inclusion, equity and access to knowledge 


\section{Conclusion}

The research on the digital literacy context yielded abundant information, which posed a challenge to data interpretation. In the midst of density, the methodology allowed the organisation of results for meta-analysis, from which the following conclusions can be highlighted.

Methodologically, this meta-research and the network analysis made it possible to achieve the objective of identifying the relationships, themes and focus of the different terms associated with research about digital literacy. Also, the methodology allowed for the understanding of other unforeseen findings that gave value to the study, localising the important position of some terms such as: digital divide, health literacy, critical literacy, scientific literacy, among others.

The study identified the key term "digital literacy" as a common and integrating axis that encompasses the diverse perspectives. In addition, this integration made it possible to define digital literacy with two perspectives. The first focused on skills-competences for the use of technology; the second, on teaching-learning and its strategies. This double perspective allowed us to define "digital literacy" not only as the sum of a number of competences, but as a process that goes from design and implementation to the evaluation of competencies, where several features are involved.

With respect to the central position of the secondary keyword "digital divide" in the network, it highlights the integral sense of digital literacy, since it places in a social framework. This places the person at the centre and his or her social inclusion in the opportunities offered by technology, a focus which is sometimes overshadowed by instrumental vision and in basic, less critical, global and transversal competencies. In this context, it is important to remark the transversality of digital literacy to human life and the importance of connecting it with learning needs and motivations. Ultimately, digital literacy is substantive to lifelong learning.

Meta-research is an interdisciplinary approach that favours the interdisciplinary nature, and data science offer new schemes to investigate. This study reflects dialogical points between sciences, which show the possibility of interdisciplinary approaches to a social phenomenon in a more comprehensive way connecting, in this case, the technological vision with the social challenges.

\section{References}

Aesaert, Koen; Vanderlinde, Ruben; Tondeur, Jo; Van-Braak, Johan (2013). "The content of educational technology curricula: a cross-curricular state of the art". Educational technology research and development, v. 61, n. 1, pp. 131-151. https://doi.org/10.1007/s11423-012-9279-9

Aguaded, Ignacio; Marín-Gutiérrez, Isidro; Caldeiro-Pedreira, Mari-Carmen (2018). "Desarrollo de la competencia mediática en el contexto Iberoamericano". Revista Letral, n. 20, pp. 156-182.

https://revistaseug.ugr.es/index.php/letral/article/view/7814

Ala-Mutka, Kristi; Punie, Yves; Redecker, Christine (2008). Digital competence for lifelong learning. European Commission. ftp://jrc.es/pub/EURdoc/JRC48708.TN.pdf

Bawden, David (2008). “Origins and concepts of digital literacy". In: Lankshear, Colin; Knobel, Michele (eds.). Digital literacies: Concepts, policies and practices. New York, NY: Peter Lang, pp. 17-32. ISBN: 9781433101694 http://citeseerx.ist.psu.edu/viewdoc/download?doi=10.1.1.741.4617\&rep=rep1\&type=pdf

Booth, Andrew; Papaioannou, Diana; Sutton, Anthea (2012). Systematic approaches to a successful literature review. London: Sage. ISBN: 9781473912465

Buckingham, David (2003). Media education: Literacy, learning and contemporary culture. Cambridge: Polity. ISBN: 978 0745659411

Burnhein, Robert (1992). "Information literacy - A core competency". Australian academic \& research libraries, v. 23, n. 4, pp. 188-196.

https://doi.org/10.1080/00048623.1992.10754796

Cope, Bill; Kalantzis, Mary (eds.) (1999). Multiliteracies: Literacy learning and the design of social futures. New York: Routledge. ISBN: 0415214211

De-Nooy, Wouter; Mrvar, Andrej; Batagelj, Vladimir (2005). "Structural analysis in the social sciences. Exploratory social network analysis with Pajek". New York: Cambridge University Press. ISBN: 0521602629

Erstad, Ola (2006). "A new direction?: Digital literacy, student participation and curriculum reform in Norway". Education and information technologies, v. 11, n. 3-4, pp. 415-429.

https://doi.org/10.1007/s10639-006-9008-2 
Eshet-Alkalai, Yoram (2004) "Digital literacy: A conceptual framework for survival skills in the digital era". Journal of educational multimedia and hypermedia, v. 13, n. 1, pp. 93-106.

https://www.learntechlib.org/primary/p/4793

European Commission (2007). Competencias clave para el aprendizaje permanente. Un marco europeo. Luxembourg: Publications Office of the European Union.

http://bit.ly/1TG5MPU

Ferrari, Anusca (2012). Digital competence in practice: An analysis of frameworks. European Commission. Luxembourg: Publications Office of the European Union.

https://pdfs.semanticscholar.org/851f/ebe72df176a16ad6e26b00ff5df35520da34.pdf

Ferrari, Anusca (2013). DigComp: A framework for developing and understanding digital competence in Europe. European Commission.

https://ec.europa.eu/jrc/en/publication/digcomp-framework-developing-and-understanding-digital-competence-europe

Ferrés, Joan; Masanet, Maria-José; Mateus, Julio-César (2018). "Three paradoxes in the approach to educational technology in the education studies of the Spanish universities". International journal of educational technology in higher education, v. 15, art. 15.

https://doi.org/10.1186/s41239-018-0097-y

Gallardo-Echenique, Eliana E.; Minelli-de-Oliveira; Marqués-Molias, Luis; Esteve-Mon, Francesc (2015). “Digital competence in the knowledge society". Journal of online learning \& teaching, v. 11, n. 1, pp. 1-16.

https://jolt.merlot.org/vol11no1/Gallardo-Echenique_0315.pdf

Gillen, Julia; Barton, David (2010). Digital literacies: Research briefing for the TLRP-TEL. Technology Enhanced Learning: Literacy Research Centre.

http://bit.ly/25uhcSA

Grandjean, Martin (2016). "A social network analysis of Twitter: Mapping the digital humanities community". Cogent arts \& humanities, v. 3, n. 1, 1171458.

https://doi.org/10.1080/23311983.2016.1171458

Ilomäki, Liisa; Kantosalo, Anna; Lakkala, Minna (2011). “What is digital competence?”. In: Linked portal. Brussels: European Schoolnet.

https://researchportal.helsinki.fi/en/publications/what-is-digital-competence

Ilomäki, Liisa; Paavola, Sami; Lakkala, Minna; Kantosalo, Anna (2016). “Digital competence - an emergent boundary concept for policy and educational research". Education and information technologies, v. 21, n. 3, pp. 655-679.

https://doi.org/10.1007/s10639-014-9346-4

International ICT Literacy Panel (2002). Digital transformation: A framework for ICT literacy. A report of the International ICT Literacy Panel. Educational Testing. Princeton, NJ: Educational Testing Service.

https://www.ets.org/Media/Research/pdf/ICTREPORT.pdf

Ioannidis, John P. A.; Fanelli, Danielle; Dunne, Debbie D.; Goodman, Steven N. (2015). “Meta-research: Evaluation and improvement of research methods and practices". PLoS biology, v. 13, n. 10, 1002264.

https://doi.org/10.1371/journal.pbio.1002264

ITEA (2007). Standards for technological literacy: Contents for the study of technology. Reston, VA: International Technology Education Association.

https://www.iteea.org/42511.aspx

Leahy, Denise; Wilson, Diana (2014). “Digital skills for employment”. In: IFIP Conference on information technology in educational management (ITEM) and IFIP Conference on key competencies for educating ICT professionals (Kcictp), pp. 178-189.

https://hal.inria.fr/hal-01342700/document

Leu, Donald J.; Kinzer, Charles K.; Coiro, Julie; Castek, Jill; Henry, Laurie A. (2017). “New literacies: A dual-level theory of the changing nature of literacy, instruction, and assessment". Journal of education, v. 197, n. 2, pp. 1-18.

https://doi.org/10.1177/002205741719700202

Mackey, Thomas P.; Jacobson, Trudi E. (2010). "Reframing information literacy as a metaliteracy". College \& research libraries, v. 72, n. 1, pp. 62-78.

https://doi.org/10.5860/crl-76r1

Martin, Allan (2006). "Literacies for the digital age: Preview of Part I". In: Martin, Allan; Madigan, Dan (eds.). Digital literacies for learning. London: Facet Publishing, pp. 3-25. ISBN: 9781856045636 
Martínez-Bravo, María-Cristina; Sádaba-Chalezquer, Charo; Serrano-Puche, Javier (2018). "Desarrollo de competencias digitales en comunidades virtuales: Un análisis de ScolarTIC". Prisma social, v. 20, pp. 129-159.

https://revistaprismasocial.es/article/view/2318/2478

Naval, Concepción; Serrano-Puche, Javier; Sádaba-Chalezquer, Charo; Arbués, Elena (2016). "Sobre la necesidad de desconectar: algunos datos y propuestas". Education in knowlegde society, v. 17, n. 2, pp. 73-90.

https://doi.org/10.14201/eks20161727390

Pérez-Escoda, Ana; García-Ruiz, Rosa; Aguaded, Ignacio (2019). “Dimensions of digital literacy based on five models of development". Cultura y educación, v. 31, n. 2, pp. 232-266.

https://doi.org/10.1080/11356405.2019.1603274

Pérez-Tornero, José-Manuel; Varis, Tapio (2012). Alfabetización mediática y nuevo humanismo. Editorial UOC. ISBN: 978 8497885126

Redecker, Christine; Punie, Yves (2019). European framework for the digital competence of educators: DigCompEd. Publications Office of the European Union, Luxembourg. ISBN: 9789279734946

https://doi.org/10.2760/159770

Scolari, Carlos A.; Masanet, Maria-José; Guerrero-Pico, Mar; Establés, María-José (2018). “Transmedia literacy in the new media ecology: Teens' transmedia skills and informal learning strategies". El profesional de la información, v. 27, n. 4, pp. 801-812.

https://doi.org/10.3145/epi.2018.jul.09

Siddiq, Fazilat; Gochyyev, Perman; Wilson, Mark (2017). "Learning in digital networks - ICT literacy: A novel assessment of students' $21^{\text {st }}$ century skills". Computers and education, v. 109, pp. 11-37.

https://doi.org/10.1016/j.compedu.2017.01.014

Suárez-Rodríguez, Jesús; Almerich, Gonzalo; Orellana, Natividad; Díaz-García, Isabel (2018). "A basic model of integration of ICT by teachers: competence and use". Educational technology research and development, v. 66, n. 5, pp. 1165-1178.

https://doi.org/10.1007/s11423-018-9591-0

Van-Deursen, Alexander J. A. M. (2012). "Internet skill-related problems in accessing online health information". International journal of medical informatics, v. 81, n. 1, pp. 61-72.

https://doi.org/10.1016/j.ijmedinf.2011.10.005

Van-Deursen, Alexander J. A. M.; Van-Dijk, Jan A. G. M. (2014). "The digital divide shifts to differences in usage". New media \& society, v. 16, n. 3, pp. 507-526.

https://doi.org/10.1177/1461444813487959

Van-Laar, Ester; Van-Deursen, Alexander J. A. M.; Van-Dijk, Jan A. G. M.; De-Haan, Jos (2017). "The relation between $21^{\text {st }}$-century skills and digital skills: A systematic literature review". Computers in human behavior, v. 72, pp. 577-588. https://doi.org/10.1016/j.chb.2017.03.010.

Voogt, Joke; Pareja-Roblin, Natalie (2012). "A comparative analysis of international frameworks for $21^{\text {st }}$ century competences: Implications for national curriculum policies". Journal of curriculum studies, v. 44, n. 3, pp. $299-321$.

https://doi.org/10.1080/00220272.2012.668938

Vuorikari, Riina; Punie, Yves; Carretero, Stephanie; Van-den-Brande, Lieve (2016). DigComp 2.0: The digital competence framework for citizens. Update phase 1: the conceptual reference model. Luxembourg Publication Office of the European Union.

https://doi.org/10.2791/11517

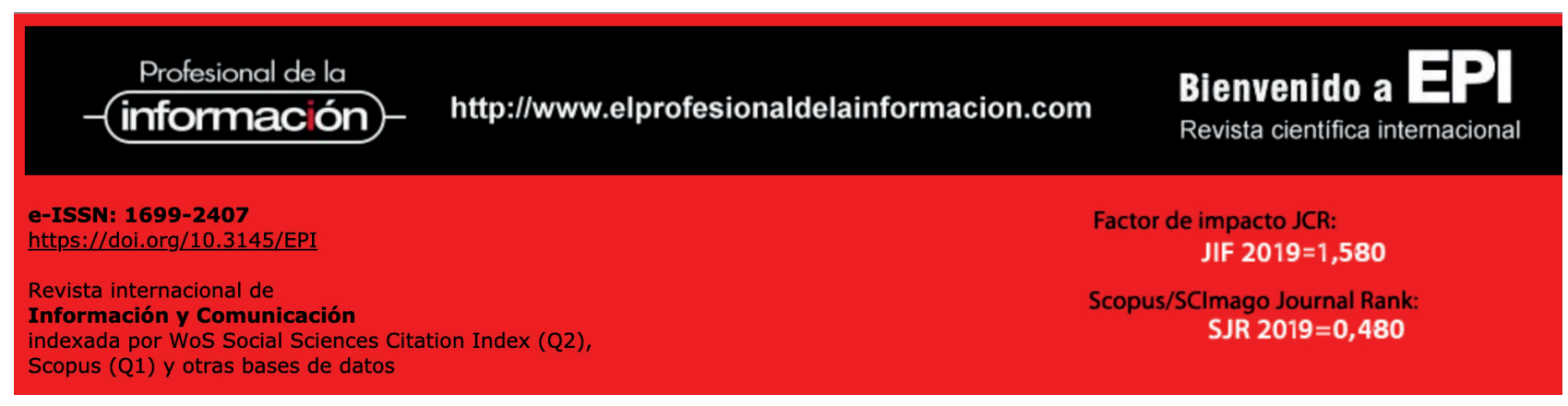

